\title{
Influences of extracellular polymeric substances (EPS) for autoaggregation of Pseudomonas putida CP1 during growth on mono-chlorophenol
}

\author{
Wan Syaidatul Aqma ${ }^{1^{\star}}$ and Brid Quilty ${ }^{2}$ \\ ${ }^{1}$ School of Bioscience and Biotechnology, Faculty of Science and Technology, Universiti Kebangsaan Malaysia, 43600 \\ Bangi, Selangor, Malaysia. \\ ${ }^{2}$ School of Biotechnology, Faculty of Science and Health, Dublin City University, Dublin 9, Ireland. \\ Email: syaidatul@ukm.edu.my
}

Received 8 July 2014; Received in revised form 8 January 2015; Accepted 13 January 2015

\begin{abstract}
Aims: Pseudomonas putida CP1 exhibits substrate-dependent autoaggregation during the degradation of 100 ppm 2chlorophenol, 100 ppm 3-chlorophenol and 200 ppm 4-chlorophenol. This study discussed the production of extracellular polymeric substances (EPS) by the organism for the formation of aggregates.

Methodology and results: Aggregation was accompanied by the production of extracellular polymeric substances (EPS). The extent of EPS production and the size of the aggregates increased with increasing stress as did the aggregation index and the hydrophobicity of the cells. A biochemical analysis of the EPS showed that the main constituents were carbohydrate $(40 \% \mathrm{w} / \mathrm{v})$ and protein $(50 \% \mathrm{w} / \mathrm{v})$ together with lower levels of DNA $(<10 \% \mathrm{w} / \mathrm{v})$.

Conclusion, significance and impact study: Given that the aggregated form of the bacterium has shown potential for use in bioaugmentation, an in-depth understanding of the phenomenon could enhance the use of this organism in biological wastewater treatment systems.
\end{abstract}

Keywords: Pseudomonas putida, autoaggregation, hydrophobicity, extracellular polymeric substances (EPS)

\section{INTRODUCTION}

In environment, bacteria presence in a freely suspended cells but most preferably to be in cell aggregates that are either freely floating or attached to surfaces as biofilms (Klebensberger et al., 2006). The process involves molecular events that encompass mechanisms for adhesion, aggregation and community expansion and facilitated by autoaggregation factor. These factors allow bacteria to autoaggregate, a phenomenon observed under the microscope as a clumping of cells and, macroscopically as flocculation and settling of cells from liquid suspension (Windt et al., 2006). Greater attention has been directed at structurally evaluating biofilms while suspended aggregates are also an important type of growth in a number of microbiological applications. The ability of microorganism to aggregate spontaneously or to assume upon treatment is fundamental to industrial processes from beer brewing to wastewater treatment (Dzul et al., 2011).

Chemical stress by toxic compounds is one factor among the possible triggers for active bacterial aggregation that allowed a protection mechanism and a strategy to survive (Gilbert et al., 2002). Pseudomonas aeruginosa PAO1 exhibited cell aggregation as a response to detergent stress which might serve as a survival strategy during growth with the toxic detergent SDS (Klebensberger et al., 2006). The cell aggregation behaviour of Sphingobium chlorophenolicum during degradation of pentachlorophenol (PCP) has been reported (Chang and Su, 2003). In our laboratory, growth of $P$. putida CP1 on higher concentrations of the monochlorophenols resulted in autoaggregation. Previously, Farrell and Quilty (2002) hypothesized the phenomenon as a survival response of the cells to toxic stress conditions.

Theoretically, the physicochemical properties of cell surfaces have a fundamental consequence on the autoaggregation phenomenon. When bacteria become more hydrophobic cell-to-cell adhesion increases (Liu et al., 2004). A common feature of many bacteria is the biosynthesis of extracellular polymeric substances (EPS) that can offer a protective barrier under environmental stress conditions as a survival mechanism ( $\mathrm{Pal}$ and Paul, 2008). A wide range of biopolymers is produced including polysaccharides, proteins, nucleic acid and lipids (Flemming et al., 2007). The EPS composition of aggregated cells differs in quantity, structure and nature depending on the microorganisms within the aggregates and the extraction methods (O'Toole et al., 2000). In toxic stress conditions, bacteria are stimulated to produce EPS, which significantly increases the ability of cells to 
aggregate. EPS formed by Rhodopseudomonas acidophila when growing in the presence of 2, 4dichlorophenol suggested to form a protective shield for the cells against the adverse influences from the external environment (Sheng et al., 2005).

Earlier studies in our laboratory had shown that $P$. putida CP1 is a very effective organism for use in bioaugmentation products in the biological degradation of toxic chemicals (Farrell and Quilty, 2002). The fact that the organism autoaggregates when grown under certain conditions was shown by McLaughlin et al. (2006) to offer a particular advantage to the organism when used in bioaugmentation products. However, the influence of production of EPS by the organism for autoaggregation had not previously been closely studied. This study therefore was designed to investigate phenotypic changes in the organism associated with autoaggregation so that the use of the organism in the biological treatment of waste streams could be optimised.

\section{MATERIALS AND METHODS}

\section{Microorganism and growth conditions}

Pseudomonas putida CP1 was grown in $100 \mathrm{~mL}$ of minimal medium which contained $100 \mathrm{ppm}$ 2chlorophenol, 100 ppm 3-chlorophenol, 50- and 200 ppm 4-chlorophenol. The minimal medium contained $(\mathrm{g} / \mathrm{L})$ $\mathrm{K}_{2} \mathrm{HPO}_{4}, \quad 4.36 ; \quad \mathrm{NaH}_{2} \mathrm{PO}_{4}, \quad 3.45 ; \quad\left(\mathrm{NH}_{4}\right)_{2} \mathrm{SO}_{4}, \quad 1.26$; $\mathrm{MgSO}_{4} \cdot 6 \mathrm{H}_{2} \mathrm{O}, 0.912$; and $1 \mathrm{~mL} / \mathrm{L}$ trace salts solution. The trace salts solution contained $(\mathrm{g} / 100 \mathrm{~mL}): \mathrm{CaCl}_{2} \cdot 2 \mathrm{H}_{2} \mathrm{O}$, 4.77; $\mathrm{FeSO}_{4} \cdot 7 \mathrm{H}_{2} \mathrm{O}, 0.37 ; \mathrm{CoCl}_{2} \cdot 6 \mathrm{H}_{2} \mathrm{O}, 0.37 ; \mathrm{MnCl}_{2}, 0.10$; and $\mathrm{Na}_{2} \mathrm{MoO}_{4} \cdot 2 \mathrm{H}_{2} \mathrm{O}, 0.02$. The $\mathrm{pH}$ of the medium was adjusted to 7.0 with $2 \mathrm{M} \mathrm{NaOH}$ and the medium was autoclaved at $121{ }^{\circ} \mathrm{C}$ for $15 \mathrm{~min}$. Chlorophenols were added to the flasks following sterilisation of the medium. $P$. putida CP1 was grown overnight in $10 \mathrm{~mL}$ nutrient broth, washed twice with $0.01 \mathrm{M}$ sodium phosphate buffer, $\mathrm{pH} 7.0$, and resuspended to give an optical density (OD) at $660 \mathrm{~nm}$ of 0.7 . The flasks were inoculated with a $5 \%(\mathrm{v} / \mathrm{v})$ inoculum, which corresponded to approximately $4 \times 10^{8} \mathrm{cells} / \mathrm{mL}$, and were incubated at $150 \mathrm{rpm}$ at $30{ }^{\circ} \mathrm{C}$ for up to 4 days.

\section{Determination of aggregation index}

The aggregation index (AI) of the cells was determined as the relative decrease of the optical density of a bacterial suspension at $660 \mathrm{~nm}$ after slow centrifugation at 4000 rpm for 2 min as described by Windt et al. (2006).

\section{Measurement of hydrophobicity}

The relative hydrophobicity was measured according to bacterial adherence to hydrocarbons (BATH). Twenty milliliter of culture was washed and suspended in $5 \mathrm{~mL}$ of $0.01 \mathrm{M}$ sodium phosphate buffer $\mathrm{pH} 7.0$ to give an optical density at $400 \mathrm{~nm}$ of 0.6 . A total of $0.3 \mathrm{~mL}$ of $n$ hexadecane (Sigma) was added to $3 \mathrm{~mL}$ of bacterial cell suspension in acid-washed test tubes. The suspension was vortex for $1 \mathrm{~min}$ to ensure mixing and then left to stand for $15 \mathrm{~min}$ to allow separation of the two phases. The aqueous phase was carefully removed using a Pasteur pipette and the OD at $400 \mathrm{~nm}$ was read. The percentage of the cells bound to $n$-hexadecane was calculated using the equation:

$$
\text { BATH }(\%)=\frac{1-\text { OD } 400 \text { of aqueous layer }}{\text { OD400 of washed cells }} \times 100
$$

\section{Viability test}

The Live/Dead Baclight Bacterial viability kit (Molecular Probes, Invitrogen) was used to determine the viability of bacterial cultures. The fluorescence of SYTO 9 and PI was detected by excitation/emission at $480 / 500 \mathrm{~nm}$ (FITC) for SYTO 9 and 490/635 nm (TRITC) for PI. Live cells fluoresced green while dead cells fluoresced red. The individual images captured from FITC and TRITC filters were merged and the percentage of live/dead cells was calculated using the Nikon NIS-Elements software.

\section{Fluorochrome staining}

The staining procedure was performed on aggregated bacterial cells to detect biochemical components as previously described by Chen et al. (2007). FITC (10 g/L; $2.5 \mu \mathrm{L})$ stains all protein and amino-sugars, calcofluor white solution $(10 \mu \mathrm{L})$ to stain the polysaccharides and SYTO $63(1.5 \mu \mathrm{L})$ to stain the nucleic acid. Aggregates were observed with an epifluorescent microscope (Nikon Ti-E) or confocal laser scanning microscope (Leica DM IRE2 microscope connected to a Leica SP2 AOBS, Leica, Germany).

\section{Aggregates sizing}

The epifluorescence microscopy (Nikon Ti-E) was used with phase-contrast settings to determine the size of aggregates. The size was calculated using the object area measurement tool in Nikon NIS-Elements software.

\section{Extraction of extracellular polymeric substances (EPS)}

The extraction of EPS was based on a modification of the method of Eboigbodin and Biggs (2008). The cell pellet was used for extraction of the bound EPS and the supernatant was used for the free EPS extraction. The polysaccharide content of the EPS was determined by the phenol sulphuric acid method with glucose as the standard. The protein content of EPS was determined by the Bradford method with bovine serum albumin as the standardand the deoxyribonucleic acid (DNA) content was determined by the diphenylamine assay with calf thymus DNA used as calibration standard. 


\section{Statistical analysis}

All experiments were repeated three times with triplicate samples. Data were analysed by two-way ANOVA using SPSS Statistics v.19 (IBM Corporation, Somers, NY). The significance of treatments was determined by Duncan's multiple range tests $(p<0.05)$.

\section{RESULTS AND DISCUSSION}

The formation of aggregates of cells was observed after $72 \mathrm{~h}$ growth on $100 \mathrm{ppm} 2$-chlorophenol and $200 \mathrm{ppm}$ 4chlorophenol and after $96 \mathrm{~h}$ in the presence of $100 \mathrm{ppm}$ 3-chlorophenol. No aggregate formation was observed during growth on the lower concentration of $50 \mathrm{ppm}$ 4chlorophenol. The ability to autoaggregates were reflected with the ability of $P$. putida CP1 to degrade the substrates, where 4-chlorophenol> 2- chlorophenol> 3chlorophenol. This suggested the level of substrate toxicity influence the stress level in $P$. putida CP1. A study by Neumann et al. (2005) revealed that cells of different bacterial species enlarged the cell size when grown in a membrane-affecting toxicant medium. They suggested that bigger cell size decreased the relative surface of a cell and consequently reduced the attachable surface for toxic aromatic compounds. Another environmental stress factor could contribute to the formation of aggregates. $P$. putida CZ1 isolated from heavy metal-contaminated soil performed unsaturated biofilm growth during response to $\mathrm{pH}$, temperature and osmotic stress (Lin et al., 2014). Vejmelkova et al. (2012) monitored the formation of Nitrosomonas aggregates as the adaptation response when oxygen identified as a stressful factor in bioreactors.

The highest viability percentage was observed when the organism was grown on 4-chlorophenol and lowest viability when the organism was grown on 2-chlorophenol and 3-chlorophenol (Table 1). Figure 1 illustrates aggregation of the cells. The aggregated cells of $P$. putida CP1 grown on mono-chlorophenol were observed to be viable suggesting that the aggregate was affording a protective mechanism to the cell. Putrinš et al. (2010) found that exposure of $P$. putida culture to phenol had only a few dead cells thus indicating that they maintained membrane homeostasis. They suggested that was an adaptive mechanism to gain time to repair the phenolcaused membrane damage. Halan et al. (2011) identified biofilm-grown Pseudomonas sp. strain VLB120 $\Delta$ C cells adapted much better to toxic concentrations of styrene, as nearly $65 \%$ of biofilm cells were viable, compared to only $7 \%$ in planktonic cultures. These findings proposed the robustness of biofilms under stress conditions.

The aggregation index, cell surface hydrophobicity and size of the aggregates are shown in Table 1. When cell aggregation was observed, the aggregation index and hydrophobicity significantly increased $(p<0.05)$ with time of incubation. Two species, Burkholderia cepacia capable of degrading $n$-alkanes and Burkholderia multivorans capable of degrading naphthalene as sole substrate showed an ability to form biofilms by the increase in cell surface hydrophobicity (Chakraborty et al., 2010). A study

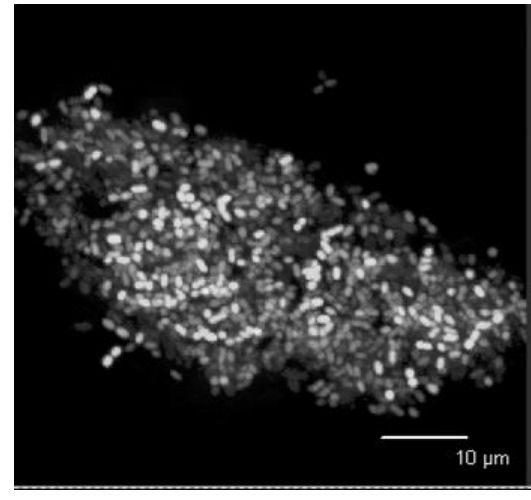

Figure 1: CLSM image of $P$. putida CP1 aggregates stained with the Live/Dead stain following growth on 100 ppm 3-chlorophenol for 4 days.

conducted by Gogra et al. (2010) showed a positive correlation between cell surface hydrophobicity and autoaggregation ability in diethyl phthalate (DEP) degrading organisms Escherichia coli, Staphylococcus aureus and Aspergillus niger.

The levels of both bound and free EPS were quantified (Figure 2). The levels of bound EPS were higher compared to the levels of free EPS in all treatments. The primary role of bound EPS may not be in the initial cell-to-cell adhesion but in holding cells together after adhesion and free EPS can induce cell aggregation (Eboigbodin and Biggs, 2008). The production of EPS by $P$. putida $\mathrm{CP} 1$ during growth on mono-chlorophenols correlated with the ability to autoaggregate and the size of the aggregates. In the absence of cell aggregation, the levels of EPS did not change significantly with time when the bacterium was grown on $50 \mathrm{ppm}$ 4-chlorophenol. Where cell aggregation occurred, the levels of EPS increased steadily until day 4 . The highest levels of EPS were detected when the organism was grown on 3chlorophenol, then 2-chlorophenol and then 200 ppm 4chlorophenol. EPS production in P. putida CP1 related to the degree of substrate toxicity where total EPS was highest in 3-chlorophenol, thus suggesting that EPS production was a toxic stress protection mechanism. The viability in $P$. putida CP1 aggregates grown on monochlorophenol is suggested to be related to the production of EPS that provided protection to the cells. A study conducted by Ueshima et al. (2008) revealed the potential of EPS to enhance the viability of a $P$. putida biofilm during exposure to cadmium. The toxic effect of cadmium was minimised by its binding to the EPS. The presence of EPS in a biomass sample enhances copper adsorption capacity on Bacillus subtilis cells and P. putida cells. The study suggested that EPS considered as an outer envelope shielding the cell surface from proton and metal exposure (Fang et al., 2011).

Analysis of the EPS showed that the main components of the EPS were carbohydrate and protein in approximately equal proportions. The third component of 
the EPS was DNA which formed less than $10 \%$ of the EPS (Figure 3). The distribution of the biochemical components of the EPS were seen to be scattered throughout the cells based on a cross-section of the aggregates (Figure 4). Jorand et al. (1998) suggested that carbohydrate plays the major role in aggregation. The composition of EPS determines the type and extent of the protective advantages (Davenport et al., 2014). Better bioflocculation at higher concentrations of proteins and carbohydrates in total EPS occurred with the increase ofelectrostatic interactionsattributed to polymeric interactions (Badireddy et al., 2010).

Table 1: Changes in viability, aggregation index (Al), cell surface hydrophobicity (BATH \%) and aggregate size when $P$. putida CP1 was grown on 100 ppm 2-chlorophenol, 100 ppm 3-chlorophenol, 200 and 50 ppm 4-chlorophenol for four days. The aggregation index and hydrophobicity significantly increased $(p<0.05)$ with time of incubation when cell aggregation was observed.

\begin{tabular}{|c|c|c|c|c|}
\hline \multirow[t]{2}{*}{ Analysis } & \multicolumn{4}{|c|}{ Day } \\
\hline & 1 & 2 & 3 & 4 \\
\hline \multicolumn{5}{|l|}{ 100ppm 2-CP } \\
\hline Viability (\%) & $97 \pm 6.3$ & $80 \pm 6.9$ & $65 \pm 5.7$ & $64 \pm 7.7$ \\
\hline $\mathrm{Al}$ & $0.55 \pm 0.05$ & $0.67 \pm 0.13$ & $0.72 \pm 0.04$ & $0.9 \pm 0.02$ \\
\hline BATH \% & $17 \pm 1.68$ & $28 \pm 1.06$ & $29 \pm 2.4$ & $44 \pm 1.01$ \\
\hline Size $\mu m^{2}\left(10^{3}\right)$ & - & - & $5.45 \pm 0.26$ & $19.15 \pm 0.43$ \\
\hline \multicolumn{5}{|l|}{ 100ppm 3-CP } \\
\hline Viability (\%) & $81 \pm 7$ & $70 \pm 7.5$ & $64 \pm 10$ & $62 \pm 5$ \\
\hline $\mathrm{Al}$ & $0.35 \pm 0.19$ & $0.48 \pm 0.19$ & $0.90 \pm 0.02$ & $0.94 \pm 0.08$ \\
\hline BATH \% & $10 \pm 1.42$ & $30 \pm 1.25$ & $40 \pm 1.42$ & $52 \pm 1.7$ \\
\hline Size $\mu m^{2}\left(10^{3}\right)$ & - & - & - & $22.47 \pm 2.96$ \\
\hline \multicolumn{5}{|l|}{ 200ppm 4-CP } \\
\hline Viability (\%) & $94 \pm 7.4$ & $83 \pm 5.5$ & $78 \pm 5.4$ & $76 \pm 8$ \\
\hline $\mathrm{Al}$ & $0.32 \pm 0.05$ & $0.21 \pm 0.1$ & $0.6 \pm 0.18$ & 0.88 \\
\hline BATH \% & $10 \pm 0.79$ & $10 \pm 1.07$ & $14 \pm 0.75$ & $32 \pm 1.64$ \\
\hline Size $\mu m^{2}\left(10^{3}\right)$ & - & - & $3.94 \pm 1.2$ & $9.35 \pm 1.2$ \\
\hline \multicolumn{5}{|l|}{ 50ppm 4-CP } \\
\hline Viability (\%) & $97 \pm 6$ & $92 \pm 6.8$ & $81 \pm 16.7$ & $80 \pm 9.4$ \\
\hline $\mathrm{Al}$ & $0.3 \pm 0.08$ & $0.21 \pm 0.1$ & $0.25 \pm 0.03$ & $0.27 \pm 0.01$ \\
\hline BATH \% & $2 \pm 0.38$ & $6 \pm 0.94$ & $4 \pm 1.02$ & $6 \pm 0.93$ \\
\hline Size $\mu m^{2}\left(10^{3}\right)$ & - & - & - & - \\
\hline
\end{tabular}

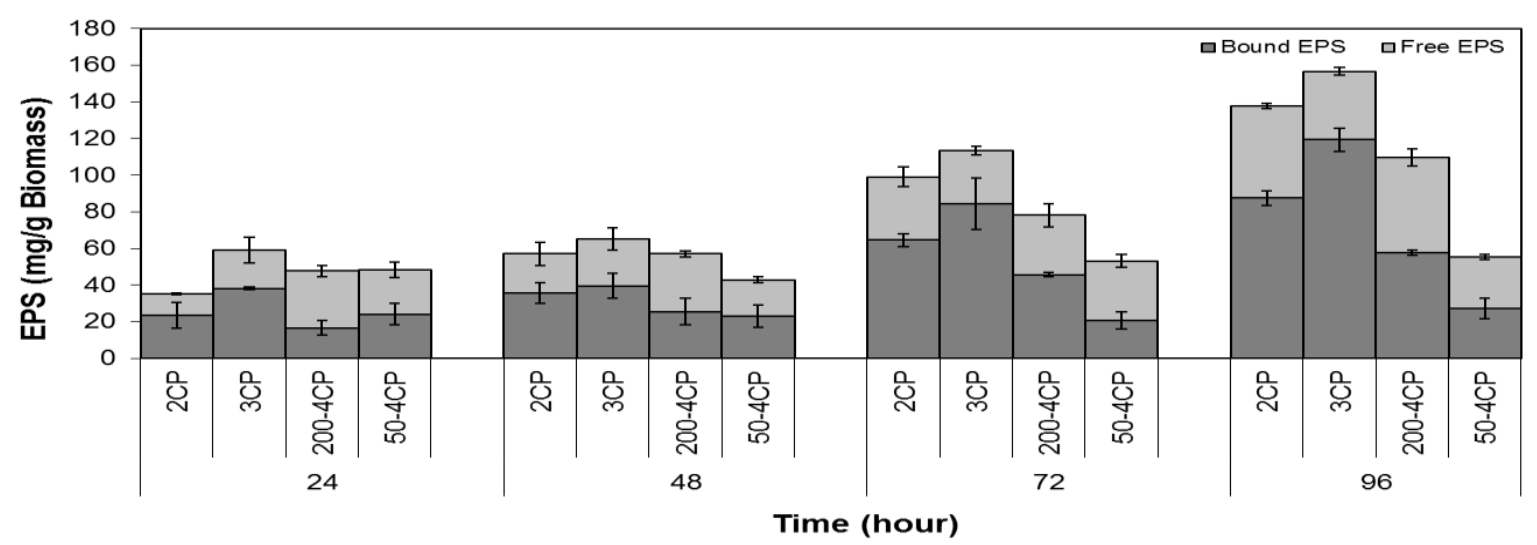

Figure 2: Distribution of bound and free EPS during growth of $P$. putida CP1 on 100 ppm 2-chlorophenol, 100 ppm 3chlorophenol, 200 and 50 ppm 4-chlorophenol. 


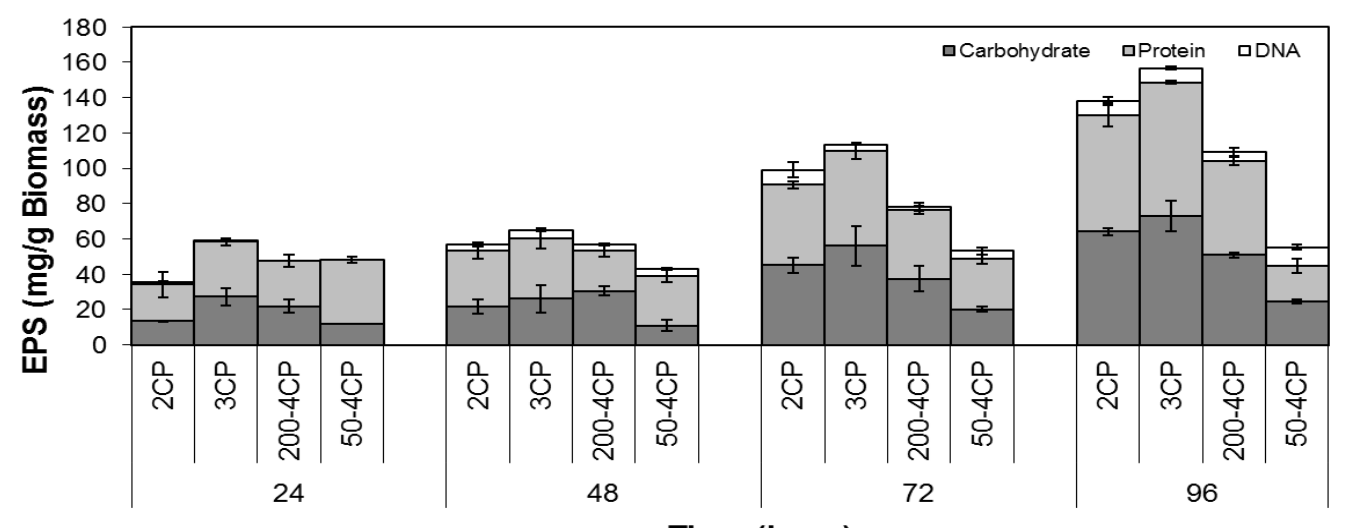

Time (hour)

Figure 3: Biochemical composition of total EPS during growth of $P$. putida CP1 on 100 ppm 2-chlorophenol, 100 ppm 3chlorophenol, 200 and 50 ppm 4-chlorophenol.

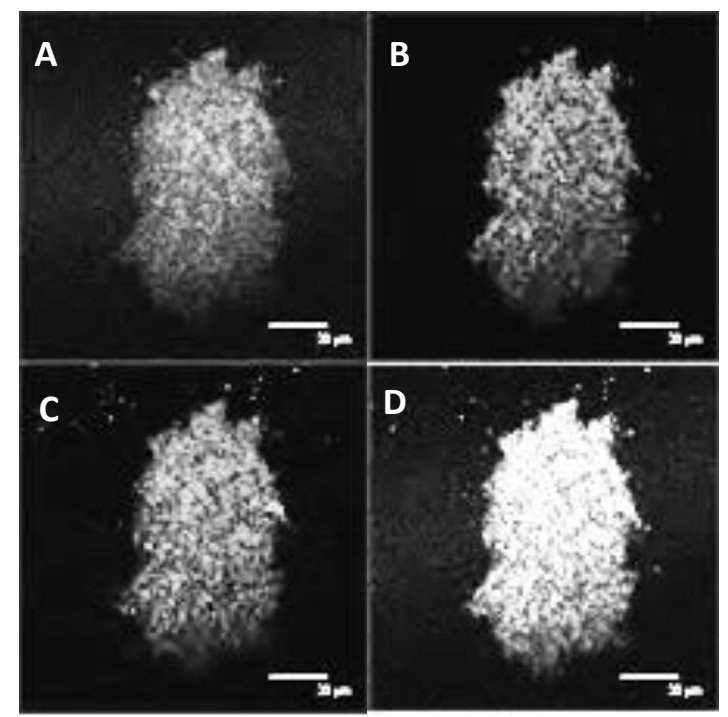

Figure 4: CLSM image of $P$. putida CP1 aggregated cells following growth on 100 ppm 3-chlorophenol for four days. A, FITC; B, SYTO 63; C,Calcofluor white and D, combined multi-channel image.

Carbohydrates are believed to protect bacterial cells from desiccation, heavy metals, organic compounds or other environmental stresses, including host immune responses and to produce biofilms (Onbasli and Aslim, 2009). Investigations of the biofilm-grown Pseudomonas sp. strain VLB120 $\Delta$ C cells revealed an increase in polysaccharide production upon solvent addition, suggested a major role of polysaccharides in structural integrity and enhanced biofilm tolerance toward toxic environments (Halan et al., 2011). It was reported the cells of $E$. coli and Salmonella exhibit an aggregative behavior during copper stressed. The cells produce the extracellular polysaccharide under these conditions and lack of this compound increased $\mathrm{Cu}$ toxicity (Dupont et al., 2011). The bound EPS of $P$. aeruginosa biofilms that is polysaccharide rich has a minor role in the ability of
EPS to protect biofilm communities from antibiotic exposure by decreasing antibiotic access to the cell. Acinetobacter baumannii EPS contained capsular polysaccharides which convey protective advantages for the cells against tobramycin exposure (Davenport et al., 2014).

The function of proteins in the formation of aggregated cells is known to be associated with the primary adhesion events during cell attachment and biofilm development. In addition, protein has a role as exoenzymes in the exopolymer matrix (Jahn et al., 1999). The protein contribution to aggregate binding strength is explained by hydrophobic interactions and polyvalent cations bridging to increase the stability of the biopolymer network (Jorand et al., 1998). The main component of $P$. putida CZ1 EPS was extracellular protein that allowed the cells in biofilm 
adhere tightly together to maintain the microenvironment (Lin et al., 2014). Wang et al. (2012) identified the component of EPS influenced the natural organic matter biosorption. $P$. aeruginosa, whose primary EPS component is polysaccharides and $P$. putida, secreting protein based EPS, behaved differently for natural organic matter biosorption, due to its hydrophobicity and the structural characteristics of proteins.

A low level of DNA present in the EPS has been suggested to indicate the presence of few dead or lysed cells (Sheng et al., 2010). However, in this study, the levels of DNA did not increase while the numbers of dead cells in the aggregates did increase. Suzuki et al. (2009) pointed out that DNA is not only the result of cell lysis but can also result from the active production of extracellular nucleic acid. Delivery of DNA outside the cell can occur via the formation of membrane vesicles or can originate from lysis or autolysis induced by stress (Klebensberger et al., 2006). The accumulation of DNA within the aggregate matrix is proposed to contribute to the structural stability of aggregates (Liao et al., 2001).

The ability of autoaggregation of the $P$. putida CP1 aided by the production of EPS could help in biological treatment of waste streams and influence the effluent quality. A study conducted by Xie et al. (2013) showed the poor aggregation of bacteria not only deteriorated the effluent quality, but also decreased the potential yield of hydrogen from substrate. The production of EPS in secretion of protein containing more disulfide bonds enhanced the stability of aggregates. Generally, the biodegradation of organic compounds exist in municipal and industrial effluents accomplished using the activated sludge process where microorganisms exist as large aggregates in EPS matrix. However, Badireddy et al. (2010) proposed that gross EPS concentrations alone do not determine microorganism aggregation. The excessive amounts of EPS might be detrimental to the process, thus will reduce efficiency of liquid solid separation in the secondary settling tank or clarifier. They revealed that certain protein secondary structures and acylated polysaccharides present in EPS shown to play important roles in aggregation and adhesion of microorganisms.

Further, even though the current study highlighted concentrations of certain EPS moieties with aggregation ability, extended work is necessary to understand the fundamental mechanisms by which certain secondary structures and functionalised component induce aggregation. Future studies should also be directed toward elucidating the molecular mechanisms underlying stress responses in aggregates that can be beneficial for further exploration of bacterial resistance and response mechanisms to other environmental stresses. Understanding these mechanismsis important for exploiting the full potential of aggregation for biotechnological applications.

\section{CONCLUSION}

Results of the present study show that when Pseudomonas putida CP1 was grown on higher concentration of mono-chlorophenol (100 ppm 2chlorophenol, 100 ppm 3-chlorophenol and 200 ppm 4chlorophenol) the organism formed aggregates. Phenotypic changes in the organism suggested that the aggregative response was a response to substrate stress. Phenotypic changes monitored during growth on these substrates showed changes in the cell surface together with the production of EPS. EPS cements cells together and affords protection from adverse environmental conditions.

\section{ACKNOWLEDGEMENT}

This research was supported by funding from Universiti Kebangsaan Malaysia (UKM), Ministry of Higher Education of Malaysia (MoHE) and Dublin City University, Ireland.

\section{REFERENCES}

Badireddy, A. R., Chellam, S., Gassman, P. L., Engelhard, M. H., Lea, A. S. and Rosso, K. M. (2010). Role of extracellular polymeric substances in bioflocculation of activated sludge microorganisms under glucose-controlled conditions. Water Research 44, 4505-4516.

Chakraborty, S., Mukherji, S. and Mukherji, S. (2010). Surface hydrophobicity of petroleum hydrocarbon degradingBurkholderia strains and their interactions with NAPLs and surfaces.Colloids and Surfaces $B$ : Biointerfaces 78, 101-108.

Chang, Y. I. and Su, C. Y. (2003). Flocculation behavior of Sphingobium chlorophenolicum in degrading pentachlorophenol at different life stages. Biotechnology and Bioengineering 82, 843-850.

Chen, M. Y., Lee, D., J., Tay, J. H. and Show, K. Y. (2007). Staining of extracellular polymeric substances and cells in bioaggregates. Applied Microbiology and Biotechnology 75, 467-474.

Davenport, E. K., Call, D. R. and Beyenal, H. (2014). Differential protection from tobramycin by extracellular polymeric substances from Acinetobacter baumannii and Staphylococcus aureus biofilms. Antimicrobial Agents \& Chemotherapy 58, 4755-4761.

Dupont, C. L., Grass, G. and Rensing, C. (2011). Copper toxicity and the origin of bacterial resistancenew insights and applications. Metallomics 3, 11091118.

Dzul, S. P., Thornton, M. M., Hohne, D. N., Stewart, E. J., Shah, A. A., Bortz, D. M., Solomon, M. J. and Younger, J. G. (2011). Contribution of the Klebsiella pneumoniae capsule to bacterial aggregate and biofilm microstructures. Applied and Environmental Microbiology 77, 1777-1782.

Eboigbodin, K. E. and Biggs, C. A. (2008). Characterization of the extracellular polymeric substances produced by Escherichia coli using infrared spectroscopic, proteomic, and aggregation studies. Biomacromolecules 9, 686-695. 
Fang, L., Wei, X., Cai, P., Huang, Q., Chen, H., Liang, W. and Rong, X. (2011). Role of extracellular polymeric substances in $\mathrm{Cu}$ (II) adsorption on Bacillus subtilis and Pseudomonas putida. Bioresource Technology 102, 1137-1141.

Farrell, A. and Quilty, B. (2002). Substrate-dependent autoaggregation of Pseudomonas putida CP1 during the degradation of mono-chlorophenols and phenol. Journal of Industrial Microbiology \& Biotechnology 28, 316-324.

Flemming, H., Neu, T. R. and Wozniak, D. J. (2007). The EPS matrix: The 'house of biofilm cells'. Journal of Biotechnology 189, 7945-7947.

Gilbert, P., Maira-Litran, T., McBain, A. J., Rickard, A. H. and Whyte, F. W. (2002). The physiology and collective recalcitrance of microbial biofilm communities. Advances in Microbial Physiology 46, 203-256.

Gogra, A. B., Yao, J., Sandy, E. H., Zheng, S. X., Zaray, G., Koroma, B. M. and Hui, Z. (2010). Cell surface hydrophobicity (CSH) of Escherichia coli, Staphylococcus aureus and Aspergillus niger and the biodegradation of diethyl phthalate (DEP) via microcalorimetry. Journal of American Science 6, 6888.

Halan, B., Schmid, A. and Buehler, K. (2011). Real-time solvent tolerance analysis of Pseudomonas sp. strain VLB120 $\Delta \mathrm{C}$ catalytic biofilms. Applied and Environmental Microbiology 77, 1563-1571.

Jahn, A., Griebe, T. and Nielsen, P.H. (1999). Composition of Pseudomonas putida biofilms: Accumulation of protein in the biofilm matrix. Biofouling 14, 49-57.

Jorand, F., Boue-Bigne, F., Block, J. C. and Urbain, V. (1998). Hydrophobic/hydrophilic properties of activated sludge exopolymeric substances. Water Science and Technology 37, 307-315.

Klebensberger, J., Rui, O., Fritz, E., Schink, B. and Philipp, B. (2006). Cell aggregation of Pseudomonas aeruginosa strain PAO1 as an energy-dependent stress response during growth with sodium dodecyl sulfate. Archives of Microbiology 185, 417-427.

Liao, B. Q., Allen, D. G., Droppo, I. G., Leppard, G. G. and Liss, S. N. (2001). Surface properties of sludge and their role in bioflocculation and settleability. Water Research 35, 339-350.

Lin, H., Chen, G., Long, D. and Chen, X. (2014). Response of unsaturated Pseudomonas putida CZ1 biofilms to environmental stresses in relation to the EPS composition and surface morphology. World Journal of Microbiology and Biotechnology 30, 30813090.

Liu, Y., Yang, S., Tay, J., Liu, Q., Qin, L. and Li, Y. (2004). Cell hydrophobicity is a triggering force of biogranulation. Enzyme and Microbial Technology 34, 371-379.
McLaughlin, H., Farrell, A. and Quilty, B. (2006). Bioaugmentation of activated sludge with two Pseudomonas putidastrains for the degradation of 4chlorophenol. Journal of Environmental Science \& Health, Part A: Toxic/Hazardous Substances \& Environmental Engineering 41, 763-777.

Neumann, G., Veeranagouda, Y., Karegoudar, T., Sahin, Ö, Mäusezahl, I., Kabelitz, N., Kappelmeyer, U. and Heipieper, H. J. (2005). Cells of Pseudomonas putida and Enterobacter sp. adapt to toxic organic compounds by increasing their size. Extremophiles 9, 163-168.

O'Toole, G., Kaplan, H. B. and Kolter, R. (2000). Biofilm formation as microbial development. Annual Review Microbiology 54, 49-79.

Onbasli, D. and Aslim, B. (2009). Effects of some organic pollutants on the exopolysaccharides (EPSs) produced by some Pseudomonas spp. strains. Journal of Hazardous Materials 168, 64-67.

Pal, A. and Paul, A. K. (2008). Microbial extracellular polymeric substances: Central elements in heavy metal bioremediation. Indian Journal of Microbiology 48, 49-64.

Putrinš, M., Ilves, H., Lilje, L., Kivisaar, M. and Hõrak, R. (2010). The impact of ColRS two-component system and $\operatorname{Ttg} A B C$ efflux pump on phenol tolerance of Pseudomonas putida becomes evident only in growing bacteria. BMC Microbiology 10, 110-122.

Sheng, G., Yu, H. and Li, X. (2010). Extracellular polymeric substances (EPS) of microbial aggregates in biological wastewater treatment systems: A review. Biotechnology Advances 28, 882-894.

Sheng, G., Yu, H. and Yue, Z. (2005). Production of extracellular polymeric substances from Rhodopseudomonas acidophila in the presence of toxic substances. Applied Microbiology and Biotechnology 69, 216-222.

Suzuki, H., Daimon, M., Awano, T., Umekage, S., Tanaka, T. and Kikuchi, Y. (2009). Characterization of extracellular DNA production and flocculation of the marine photosynthetic bacterium Rhodovulum sulfidophilum. Applied Microbiology and Biotechnology 84, 349-356.

Ueshima, M., Ginn, B. R., Haack, E. A., Szymanowski, J. E. S. and Fein, J. B. (2008). Cd adsorption onto Pseudomonas putida in the presence and absence of extracellular polymeric substances. Geochimica Et Cosmochimica Acta 72, 5885-5895.

Vejmelkova, D., Sorokin, D.Y., Abbas, B., Kovaleva, 0. L., Kleerebezem, R., Kampschreur M. J., Muyzer, G. and van Loosdrecht, M. C. M. (2012). Analysis of ammonia-oxidizing bacteria dominating in lab-scale bioreactors with high ammonium bicarbonate loading. Applied Microbiology \& Biotechnology 93, 401-410.

Wang, Z., Hessler, C. M., Xue, Z. and Seo, Y. (2012). The role of extracellular polymeric substances on the sorption of natural organic matter. Water Research 46, 1052-1060. 
Windt, W. D., Gao, H., Kromer, W., Damme, P. V., Dick, J., Mast, J., Boon, N., Zhou, J. and Verstraete, W. (2006). AggA is required for aggregation and increased biofilm formation of a hyper-aggregating mutant of Shewanella oneidensis MR-1. Microbiology 152, 721-729.

Xie, G. J., Liu, B. F., Xing, D. F., Nan, J., Ding, J. and Ren, N. Q. (2013). Photo-fermentative bacteria aggregation triggered by L-cysteine during hydrogen production. Biotechnology for Biofuels 6, 64-78. 